\title{
Cutting performance of solid ceramic and carbide end milling tools in machining of nickel based alloy Inconel 718 and stainless steel $316 \mathrm{~L}$
}

\author{
Grguraš, D. ${ }^{a,{ }^{*}}$, Kern, M. ${ }^{a}$, Pušavec, F. ${ }^{a}$ \\ ${ }^{a}$ University of Ljubljana, Faculty of Mechanical Engineering, Laboratory for Machining, Ljubljana, Slovenia
}

\begin{abstract}
A B S T R A C T
Machining of nickel based alloys is in most of the times affected via high mechanical and thermal loads, causing high wear tendency of carbide tools, even at relatively low cutting speeds. On the other hand, ceramic as a cutting material, is more chemically stable and retains its hardness even at higher temperatures $\left(>800{ }^{\circ} \mathrm{C}\right)$ when machining difficult-to-cut materials. Therefore, to increase productivity, as an alternative to carbide tools, full body ceramic milling tools are proposed. In this paper, high speed milling process, using full body ceramic end milling tools, was analysed in parallel to carbide tools. Tool life of ceramic tools was compared with tool life of more widely used carbide tools when milling two different difficult-to-cut materials, i. e. nickel based alloy Inconel 718 and austenitic stainless steel 316L, under different cooling lubrication conditions. In addition, surface integrity and cost analysis were taken into account. Results are showing that ceramic milling tools are increasing material removal rate and productivity. However, the overall efficiency of ceramic tools can still be economically questionable.
\end{abstract}

\begin{tabular}{l} 
A R T I C L E I N F O \\
\hline Keywords: \\
Milling; \\
Ceramic end mill; \\
Carbide end mill; \\
Inconel 718; \\
Stainless steel 316L; \\
Productivity \\
*Corresponding author: \\
damir.grguras@fs.uni-lj.si \\
(Grguraš, D.) \\
Article history: \\
Received 22 August 2018 \\
Revised 4 March 2019 \\
Accepted 5 March 2019
\end{tabular}

\section{References}

[1] Jawahir, I.S., Attia, H., Biermann, D., Duflou, J., Klocke, F., Meyer, D., Newman, S.T., Pusavec, F., Putz, M., Rech, J., Schulze, V., Umbrello, D. (2016). Cryogenic manufacturing processes, CIRP Annals - Manufacturing Technology, Vol. 65, No. 2, 713-736, doi: 10.1016/j.cirp.2016.06.007.

[2] Kopač, J., Soković, M. (1993). Machining technique - Modern cutting tools, (in Slovene), University of Maribor, Faculty of Mechanical Engineering, Ljubljana, Slovenia.

[3] Čuš, F. (1996). Machining technique, (in Slovene), University of Maribor, Faculty of Mechanical Engineering, Maribor, Slovenia.

[4] Aruna, M., Dhanalakshmi, V., Mohan, S. (2010). Wear analysis of ceramic cutting tools in finish turning of Inconel 718, International Journal of Engineering Science and Technology, Vol. 2, No. 9, 4253-4262.

[5] Arunachalam, R., Mannan, M.A. (2000). Machinability of nickel-based high temperature alloys, Machining Science and Technology, Vol. 4, No. 1, 127-168, doi: 10.1080/10940340008945703.

[6] Narutaki, N., Yamane, Y., Hayashi, K., Kitagawa, T., Uehara, K. (1993). High speed machining of Inconel 718 with ceramic tools, CIRP Annals, Vol. 42, No. 1, 103-106, doi: 10.1016/S0007-8506(07)62402-0.

[7] Kitagawa, T., Kubo, A., Maekawa, K. (1997). Temperature and wear of cutting tools in high speed machining of Inconel and Ti-6Al-6V-2Sn, Wear, Vol. 202, No. 2, 142-148, doi: 10.1016/S0043-1648(96)07255-9.

[8] El-Bestawi, M.A., El-Wardany, T.I., Yan, D., Tan, M. (1993). Performance of whisker-reinforced ceramic tools in milling nickel-based alloy, CIRP Annals, Vol. 42, No. 1, 99-102, doi: 10.1016/S0007-8506(07)62401-9.

[9] Li, L., He, N., Wang, M., Wang, Z.G. (2002). High speed cutting of Inconel 718 with coated carbide and ceramic inserts, Journal of Materials Processing Technology, Vol. 129, No. 1-3, 127-130, doi: 10.1016/S0924-0136(02) $\underline{00590-3}$. 
[10] Uhlmann, E., Hübert, C. (2011). Tool grinding of end mill cutting tools made from high performance ceramics and cemented carbides, CIRP Annals, Vol. 60, No. 1, 359-362, doi: 10.1016/i.cirp.2011.03.106.

[11] Çelik, A., Sert Alağaç, M., Turan, S., Kara, A., Kara, F. (2017). Wear behavior of solid SiAlON milling tools during high speed milling of Inconel 718, Wear, Vol. 378-379, 58-67, doi: 10.1016/i.wear.2017.02.025.

[12] Wang, B., Liu, Z. (2016). Cutting performance of solid ceramic end milling tools in machining hardened AISI H13 steel, International Journal of Refractory Metals and Hard Materials, Vol. 55, 24-32, doi: 10.1016/j.ijrmhm.2015. 11.004.

[13] Grguraš, D., Kern, M., Pušavec, F. (2018). Suitability of the full body ceramic end milling tools for high speed machining of nickel based alloy Inconel 718, Procedia CIRP, Vol. 77, 630-633, doi: 10.1016/i.procir.2018.08.190.

[14] BSSA. Chemical compositions of AISI (ASTM/ASME) and UNS austenitic stainless steel grades, from $\underline{h t t p: / / w w w . ~}$ bssa.org.uk/topics.php?article $=183$ accessed January 16, 2018.

[15] ESPI Metals. Inconel 718, from http://www.espimetals.com/index.php/technical-data/91-inconel-718, accessed January 16, 2018.

[16] Krajewska-Śpiewak, J., Gawlik, J., Piekoszewski, W.; Stachura, K. (2018). Identification of residual stresses in a surface layer of Ti6AL4V and inconel 718 after process of peripheral milling, Tehnički Vjesnik - Technical Gazette, Vol. 25, No. 1, 88-91, doi: 10.17559/TV-20160531085315.

[17] Ozcelik, B., Oktem, H., Kurtaran, H. (2005). Optimum surface roughness in end milling Inconel 718 by coupling neural network model and genetic algorithm, The International Journal of Advanced Manufacturing Technology, Vol. 27, No. 3-4, 234-241, doi: 10.1007/s00170-004-2175-7.

[18] Choudhury, I.A., El-Baradie, M.A. (1998). Machinability of nickel-base super alloys: Machinability of nickel-base super alloys: A general review, Journal of Materials Processing Technology, Vol. 77, No. 1-3, 278-284, doi: 10.1016 ¿S0924-0136(97)00429-9.

[19] Maiyar, L.M., Ramanujam, R., Venkatesan, K., Jerald, J. (2013). Optimization of machining parameters for end milling of Inconel 718 super alloy using Taguchi based grey relational analysis, Procedia Engineering, Vol. 64, 1276-1282, doi: 10.1016/i.proeng.2013.09.208.

[20] Kaladhar, M., Subbaiah, K.V., Rao, C.H.S. (2012). Machining of austenitic stainless steels - A review, International Journal of Machining and Machinability of Materials, Vol. 12, No. 1-2, 178-192, doi: 10.1504/IJMMM.2012. 048564.

[21] Ravani Acciai. Austenitic stainless steel - AISI 316L, from http://www.ravaniacciai.it/aisi 316l/listtables sl 101.aspx, accessed January 16, 2018.

[22] Motorcu, A.R., Kuş, A., Arslan, R., Tekin, Y., Ezentaş, R. (2013). Evaluation of tool life - Tool wear in milling of Inconel 718 superalloy and the investigation of effects of cutting parameters on surface roughness with Taguchi method, Tehnički Vjesnik - Technical Gazette, Vol. 20, No. 5, 765-774.

[23] Alkali, A., Ginta, T.L., Abdulrani, A.M., Fawad, H., Danish, M. (2016). Study on the machinability of 316L stainless steel using flame assisted machining, Journal of Engineering and Applied Sciences, Vol. 11, No. 14, 8743-8749.

[24] Liao, Y.S., Lin, H.M., Wang, J.H. (2008). Behaviors of end milling Inconel 718 superalloy by cemented carbide tools, Journal of Materials Processing Technology, Vol. 201, No. 1-3, 460-465, doi: 10.1016/i.jmatprotec. 2007. 11.176. 


\section{APEM}

\title{
Učinkovitost uporabe keramičnih in karbidnih orodij pri obdelavi zlitine na osnovi niklja Inconel 718 in nerjavnega jekla 316L
}

\author{
Grguraš, D. ${ }^{a,}{ }^{*}$, Kern, M. ${ }^{a}$, Pušavec, $F .{ }^{a}$ \\ a University of Ljubljana, Faculty of Mechanical Engineering, Laboratory for Machining, Ljubljana, Slovenia
}

\begin{abstract}
POVZETEK
Pri strojni obdelavi zlitin na osnovi niklja so v večini primerov prisotne visoke mehanske in toplotne obremenitve, ki povzročijo visoko obrabo karbidnih orodij že pri razmeroma majhnih hitrostih rezanja. Po drugi strani je keramika kot rezalni material bolj kemično stabilna in, pri obdelavi materialov, ki se težko režejo, obdrži svojo trdoto tudi pri višjih temperaturah $\left(>800^{\circ} \mathrm{C}\right)$. Zato so za povečanje produktivnosti kot alternativa karbidnim orodjem predlagana keramična rezkalna orodja. $\mathrm{V}$ tem prispevku smo analizirali keramična in karbidna orodja v procesu visokohitrostnega rezkanja. Pod različnimi pogoji hlajenja in mazanja smo primerjali življenjsko dobo keramičnih in karbidnih orodij pri rezkanju dveh materialov, ki se težko režeta, Inconel 718 na osnovi niklja in avstenitno nerjavno jeklo 316L. Poleg tega sta bili upoštevani celovitost površine in analiza stroškov. Rezultati kažejo, da keramična orodja dosegajo večjo hitrost odstranjevanja materiala in višjo produktivnost. Vendar pa je splošna učinkovitost keramičnega orodja lahko še vedno ekonomsko vprašljiva.
\end{abstract}

(C) 2019 CPE, University of Maribor. All rights reserved.
PODATKI O ČLANKU

Ključne besede:

Rezkanje;

Keramični rezkar;

Karbidni rezkar;

Inconel 718;

Nerjavno jeklo 316L;

Produktivnost

* Kontaktna oseba: damir.grguras@fs.uni-lj.sì (Grguraš, D.)

Zgodovina članka: Prejet 22. avgusta 2018

Popravljen 4. marca 2019

Sprejet 5. marca 2019 